\title{
Ionization Source
}

National Cancer Institute

\section{Source}

National Cancer Institute. Ionization Source. NCI Thesaurus. Code C47927.

A device that converts a sample into an ion stream. 